\title{
TISSUE CULTURE STUDY FOR EFFICIENT CALLUS INDUCTION FROM INTERNODAL EXPLANTS OF Asparagus racemosus WILLD AN IMPORTANT MEDICINAL HERB
}

\author{
RITIKA KUMARI ${ }^{\mathrm{a} 1}$, ANUPAM KUMARI ${ }^{\mathrm{b}}$ AND A.K. SINGH ${ }^{\mathrm{c}}$ \\ ${ }^{\mathrm{abc}}$ Department of Botany, B.R. Ambedkar Bihar University, Muzaffarpur, Bihar, India
}

\begin{abstract}
Tissue culture study was performed to standardize the technique and select suitable plant growth regulators and their concentrations for efficient callus induction from the nodal explants of Asparagus racemosus willd, an important medicinal herb. Different concentrations of NAA, 2,4-D, BAP and KN were supplemented in MS basal medium in which the nodal explants were inoculated. It was observed that MS $+0.2 \mathrm{mg} / \mathrm{l} \mathrm{NAA}$ was the best culture condition in which maximum percentage of response $\mathbf{9 0 . 3 6}$ was obtained. This was followed by the culture conditions that were $\mathrm{MS}+2.0 \mathrm{mg} / \mathrm{l}$ where the percentage response was $88.68 \%$. Similarly, next higher percentage 88.62 was observed in MS+1.0 mg/l BAP + 1.0 mg/l NAA. It was further observed that growth rate was excellent where the percentage response was higher. Second it was noted that the calli had both compact and friable texture and their colour varied from green yellow to brown even where the growth was excellent. It was further noted that, NAA or BAP alone at higher concentration and $\mathrm{KN}$ alone at lower concentration when used alone had no response for callusing. However, $\mathrm{KN}$ at higher concentration $2.0 \mathrm{mg} / \mathrm{l}$ gave the highest percentage of response for callusing. NAA + BAP and NAA + KN at the similar concentrations gave different result. In the MS medium having $1.0 \mathrm{mg} / \mathrm{l} \mathrm{BAP}+1.0 \mathrm{mg} / \mathrm{l} \mathrm{NAA}$ the percentage of response was 88.62 while $\mathrm{MS}+1.0 \mathrm{mg} / \mathrm{l} \mathrm{KN}+1.0 \mathrm{mg} / \mathrm{l} \mathrm{NAA} \mathrm{the}$ percentage of response was 62.34 only. Growth rate of the calli also differed in different culture conditions.
\end{abstract}

KEYWORDS: Nodal Explants, Callus, Friable, Compact, Asparagus racemosus, Plant Growth Regulator

ABBREVIATIONS: $\mathrm{MS}=$ Murashige and Skoog, NAA $=$ Naphthalene acetic acid, 2,4-D = 2,4- Dichlorophenoxy acetic acid, $\mathrm{BAP}=6$, Benzyl amino purine, $\mathrm{KN}=$ Kinetin

Asparagus racemosus willd, of family Liliaceae /Asparagaceae is a thorny herbaceous climber. It is commonly called Shatavari or Shatavar in Hindi. The stem is woody, much branched and roots are tuberous. These roots bear several medicinal properties. Shatavari has been mentioned in Ayurvedic text like Charak Sanhita and Sushrut Sanhita, (Asha and Pawan, 2012). In Ayurveda the plant is called the queen of herbs and is the primary herb recommended for female health. There are several diseases for which the powdered roots of Shatavar are being given. It is beneficial in the treatment of infertility, impotency, leucorrhoea, menopause syndrome and incase of herpes and syphilis. It is also used to cure epilepsy, kidney disorders, chronic fevers, stomach ulcers, liver cancer, to increase milk secretion. Asparagus racemosus is considered as the most potent female health tonic. Its use reduces the sizzling emotions such irritability, anger, jealousy, resentment, and hatred. There are several experimental evidences that support the above action. Some of them may be cited here such as, Mathur et al., (1994), Shao et al., (1997), Mandal et al., (2000), Saxena and Chauraisa (2001), Datta et al., (2002), Goel et al., (2006), Bopana and Saxena (2007), Singh et al., (2009), Pise et al., (2011), Sharma et al., (2011), Trivedi et al., (2011), Acharya et al., (2012), Joshi et al., (2012),
Alok et al., (2013), Bansode et al., (2014). Medicinal plants do produce secondary metabolites of different groups. These phytochemicals are extracted from different parts. Because these secondary metabolites are produced at low concentration, so large number of plants is required for the extraction of these metabolites. This has posed a threat on the survival of such species. Alternative technique for the production of such secondary metabolites is tissue culture. Here the callus may be induced and such metabolites can be extracted. From these calli the cell suspension cultures can be prepared. Such cultures may exploit for enhanced rate of production of desired secondary metabolites.

Tissue culture studies of Asparagus racemosa as well other medicinal plants have been done by different workers. Some of them may be mentioned here, such as Gyulai et al (1992), Kohnura et al., (1994), Mathur et al., (1994), Mustapha et al., (1996), Dihan et al., (2001), Saxena and Chaurasia (2001), Martin (2004), Goel et al., (2006), Mehta and Subramaniyan (2005), Zhang et al (2006), Bopana and Saxena (2008), Lin et al., (2008), Nishitha and Sanjay (2008), Bakheeet (2010), Bojnauth et al., (2010), Ojha et al., (2010), Chaudhary and Dantu (2011), Sharma et al., (2012), Mahendra and Bai (2012), Renjiana et al., (2012), Anandan et al., (2012), Sharma and Sharma (2013), Bansode et al., (2014), Patel and Patel (2015), Elimira et al., (2017), Azad and Momad (2017), Pank and Joshi (2017), Chandra et al., (2018),

${ }^{1}$ Corresponding author 
Chaudhary and Dantu (2019). Keeping all these ideas in mind, tissue culture study was preformed to induce callus on nodal explants of Asparagus racemosus willd.

\section{MATERIALS AND METHODS}

\section{Plant Materials}

For obtaining sterile plant materials to be used as an explants, healthy seeds were collected from the plants growing in the university campus. Seeds were first washed with running tap water, flowed by washing with liquid detergent for 15 minutes. Above seeds were washed again with glass distilled water 3-4 times to remove the detergent. These seeds were then treated with $0.2 \%$ Bavistin solution for 5 minutes. The flasks were shaken time to time for uniform treatment of the seed surface. Above seeds were germinated on MS (Murashige and Skoog, 1962) medium, containing 3\% sucrose and $0.7 \%$ agar. The $\mathrm{pH}$ of the medium was adjusted to 5.8 , before autoclaving at $15 \mathrm{lb}$ pressure. There were no growth hormones. $12 \mathrm{ml}$ of above autoclaved medium was dispensed in 25X150 mm Borosil culture tubes under aseptic condition. When the medium solidified, it was stored and next day used for inoculation of seeds. 2-3 seeds were placed on the above medium under Laminar flow air chamber. These tubes were incubated in culture room at low light intensity. After 40 days seedlings were seen. They were sub-cultured in the same medium to get much branched and well grown plants.

In the mean time stock solutions for different constituents of MS basal medium as well different plant growth regulators were prepared separately. These stock solution had 20X and 200X concentrations. Now for the preparation of 1 liter of medium desired amount form different stock solutions were taken in one liter conical flask. With the help of sterilized distilled water the volume was made $500 \mathrm{ml}$. In another $500 \mathrm{ml}, 8 \mathrm{~g}$ of agar powder was dissolved carefully. These two solutions were mixed and $30 \mathrm{~g}$ sucrose was dissolved in it. The $\mathrm{pH}$ was adjusted to 5.8. Above culture medium was supplemented separately, 0.2, 0.5, 1.0, 1.5 and $2.0 \mathrm{mg} / 1$ of NAA, 2,4-D, BAP and Kinetin. In separate experiments the medium was supplemented with $0.2,0.5,1.0,2.0$ $\mathrm{mg} / 1 \mathrm{NAA}$ along with $0.2,0.5,1.0,2.0 \mathrm{mg} / \mathrm{l} \mathrm{BAP}$ and 0.2 , 0.5 and $1.0 \mathrm{mg} / \mathrm{l} \mathrm{NAA}+0.2,0.5$ and $1.0 \mathrm{mg} / \mathrm{l} \mathrm{KN}$ separately. $40 \mathrm{ml}$ of the molten media were dispensed in culture jar, of $250 \mathrm{ml}$. The jar was covered properly and was sterilized at $15 \mathrm{lb}$ pressure for $20 \mathrm{~min}$. All the culture jars were taken out and allowed to cool at room temperature. They were stored in freeze and used for inoculation.

Plants of Asparagus racemosus grown in the laboratory on hormone free MS medium were used for explants. Nodes were excised and pieces of $1.0 \mathrm{~cm}$ were inoculated in above prepared media, inside the laminar air flow chamber. Above culture jars with explants were incubated in culture room at $26 \pm 1^{0} \mathrm{C}$ and at 3000 lux, light produced by the cool white fluorescent tubes. The photoperiods were adjusted at $16 \mathrm{~h}$ light and $8 \mathrm{~h}$ dark. All the experiments were repeated thrice and each time 15 culture jars were inoculated and incubated. Observation was made on an alternate day. Jars showing contamination were discarded after autoclaving. Observation was also done for the total number of explants, responding for callus induction, the growth rate of calli, their texture and colour etc. Mean of the data was tabulated and used for discussion.

\section{RESULTS}

From the table 1, it may be noted that the response of the nodal explants inoculated in MS medium supplemented with different plant growth regulators at different concentrations either alone or in combinations varied considerably. It may be noted from the table 1 , that maximum percentage of response for callus induction was in MS $+0.2 \mathrm{mg} / 1 \mathrm{NAA}$ alone that was 90.36 . This was followed by the explants inoculated in MS $+0.5 \mathrm{mg} / 1$ NAA that was 82.48 . The explants, in MS $+0.2 \mathrm{mg} / 12,4-$ $\mathrm{D}$ had lower percentage of response which was 63.54 . However, in MS $+0.5 \mathrm{mg} / 1$ 2,4-D the percentage of response was 72.18. It may be further noted that the percentage of response in MS $+0.2 \mathrm{mg} / \mathrm{l} \mathrm{BAP}$ was 62.74 and in MS $+0.5 \mathrm{mg} / 1$ BAP 58.45 respectively. There was no callusing when the explants were inoculated in MS + $0.2 \mathrm{mg} / \mathrm{l} \mathrm{KN}$ or $\mathrm{MS}+0.5 \mathrm{mg} / \mathrm{l}$ of $\mathrm{KN}$. However, the percentage response for callusing in $\mathrm{MS}+2.0 \mathrm{mg} / \mathrm{K} \mathrm{KN}$ was 88.78. It may be noted from the table that in MS+2.0 $\mathrm{mg} / 1 \mathrm{NAA}$ medium there was zero response. When 1.0 $\mathrm{mg} / 1 \mathrm{NAA}+1.0 \mathrm{~m} / \mathrm{gl}$ BAP were supplemented in MS medium the percentage of response for callus induction was 88.62. Whereas $\mathrm{MS}+0.5 \mathrm{mg} / 1 \mathrm{NAA}+0.5 \mathrm{mg} / \mathrm{KN}$ induced callusing in $78.62 \%$ of the explants.

Growth rate, texture and colour of the calli were also observed. From the table it was noted that excellent growth rate was among the cultures where the percentage of response was the maximum. Similarly, the texture of the calli varied form compact to friable. However, here the texture and nature of the calli were not dependent on 
KUMARI ET AL.: TISSUE CULTURE STUDY FOR EFFICIENT CALLUS INDUCTION FROM INTERNODAL EXPLANTS ...

the percentage of response for callus induction. The

colour of the calli varied form green, to green yellow, to

brown or dark brown- or light green to light brown.

Table 1: Impact of different concentrations of cytokinins and auxins, supplemented in MS basal medium individually or in different combinations on callus induction and its growth, induced form nodal explants of Asparagus racemosus willd

\begin{tabular}{|c|c|c|c|c|c|c|c|}
\hline NAA & 2,4-D & BAP & $\mathbf{K N}$ & \% Response for callusing & Growth rate & Texture & Colour \\
\hline 0.2 & -- & -- & -- & 90.36 & ++++ & Compact & Greenish yellow \\
\hline 0.5 & -- & -- & -- & 82.48 & +++ & Compact & Green \\
\hline 1.0 & -- & -- & -- & 58.24 & ++ & Friable & Green \\
\hline 1.5 & -- & -- & -- & 46.58 & ++ & Compact & Brown \\
\hline 2.0 & -- & -- & -- & -- & -- & -- & -- \\
\hline-- & 0.2 & -- & -- & 63.54 & ++ & Friable & Greenish \\
\hline-- & 0.5 & -- & -- & 72.18 & +++ & Compact & Green \\
\hline-- & 1.0 & -- & -- & 42.64 & ++ & Compact & Brown \\
\hline-- & 1.5 & -- & -- & 61.28 & ++ & Compact & Dark Brown \\
\hline-- & 2.0 & -- & -- & 68.30 & +++ & Compact & Brown \\
\hline-- & -- & 0.2 & -- & 62.74 & ++ & Friable & Brown \\
\hline-- & -- & 0.5 & -- & 58.45 & ++ & Friable & Dark Brown \\
\hline-- & -- & 1.0 & -- & 51.26 & ++ & Friable & Light Green \\
\hline-- & -- & 1.5 & -- & -- & - & -- & -- \\
\hline-- & -- & 2.0 & -- & -- & -- & -- & -- \\
\hline-- & -- & -- & 0.2 & -- & -- & -- & -- \\
\hline-- & -- & -- & 0.5 & -- & -- & -- & -- \\
\hline-- & -- & -- & 1.0 & 47.28 & ++ & Compact & Brown \\
\hline-- & -- & -- & 1.5 & 62.34 & ++ & Compact & Green \\
\hline-- & -- & -- & 2.0 & 88.78 & ++++ & Friable & Dark Brown \\
\hline 0.2 & -- & 0.2 & -- & 43.56 & ++ & Compact & Light Brown \\
\hline 0.5 & -- & 0.5 & -- & 68.74 & ++ & Compact & Green \\
\hline 0.5 & -- & 1.0 & -- & 57.62 & ++ & Friable & Brown \\
\hline 0.5 & -- & 2.0 & -- & 73.56 & +++ & Friable & Green \\
\hline 1.5 & -- & 1.0 & -- & 62.38 & ++ & Friable & Green \\
\hline 1.0 & -- & 1.0 & -- & 88.62 & ++++ & Friable & Brown \\
\hline 2.0 & -- & 1.0 & -- & 66.54 & ++ & Compact & Brown \\
\hline 0.1 & -- & -- & 0.1 & 38.74 & ++ & Friable & Green \\
\hline 0.5 & -- & -- & 0.5 & 78.62 & ++++ & Compact & Brown \\
\hline 1.0 & -- & -- & 1.0 & 62.34 & ++ & Friable & Light Brown \\
\hline
\end{tabular}

\section{DISCUSSION}

In the present study, experiments were done to induce calli on nodal explants of Asparagus racemosus. It was observed that nodal explants responded for callusing in MS basal medium, supplemented with different concentrations of NAA and 2,4-D alone as well as with BAP and KN. Similarly, BAP and Kinetin alone were also tested for callusing. Here best response for callus induction and growth was noted on MS $+0.2 \mathrm{mg} / 1$ NAA. It was further noted that in this case increasing concentrations of the auxins had no promising impact rather there was no response for callusing in $\mathrm{MS}+2.0$ $\mathrm{mg} / 1 \mathrm{NAA}$. This was also noted in case of MS $+0.5 \mathrm{mg} / 1$ 2,4-D where there was maximum response and at MS + $0.2 \mathrm{mg} / 1 \mathrm{BAP}$ alone the response was better but at higher concentration there was no response at all. Just reverse to the above findings $\mathrm{MS}+\mathrm{KN}$ at higher concentration maximum percentage of response for callus induction 88.78 was found. It was further noted that MS $+1.0 \mathrm{mg} / 1$ $\mathrm{NAA}+1.0 \mathrm{mg} / \mathrm{l} \mathrm{BAP}$ gave better response, but either $\mathrm{NAA}$ or BAP at $1.0 \mathrm{mg} / \mathrm{l}$ had lower response. This may be due to the fact that for callusing, interaction of 
cytokinin \& auxins is essential. However, for NAA $+\mathrm{KN}$ there was lower percentage of response. Present findings corroborate with the findings of Gyulai et al., (1992), Kohmura et al., (1994), Mustapha et al., (1996), Sharma et al., (2011), Dezfuli et al., (2013), Patel and Patel (2015), Azad et al., (2017), Pank and Joshi (2017), Lamor et al., (2018), and Chaudhary and Dantu (2019). These workers induced calli for morphogenetic studies. Trivedi et al., (2010), used Thidiazuron to induce callus in $A$. racemosus. They also found that the explants had different response for callusing in different concentrations of Thidiazuron.

\section{CONCLUSION}

The calli induced are being further cultured to get embryoids, or for morphogenesis. It may be used for generation of suspension culture and production of secondary metabolites. In suspension culture we can use the precursors for specific secondary metabolite or can enhance the rate of secondary metabolite synthesis by adding elicitors. It has been reported that biomass accumulation was correlated with saponin production over 30 day culture cycle. The saponin concentration in callus raised from the explant taken from $A$. racemosus was 20 fold higher than the plants found in natural habitat. (Pise et al., 2011). Therefore, induced calli may be exploited for various purposes.

\section{ACKNOWLEDGEMENT}

The authors gratefully acknowledge the Head of Department of Botany, B.R. Ambedkar Bihar University, Muzaffarpur for providing facilities during this research work.

\section{REFERENCES}

Acharya S.R., Acharya N.S, Ghangale J.O., Saha S.K., Pandeya S.S., 2012. Antioxidant and Hepatoprotective action of Asparagus racemosus willd root extract. Ind. Journ. of Exp. Biol., 50(11): 795-801.

Alok S., Jain S.K., Verma A., Kumar M., Mahor A. and Sabharwal M., 2013. Plant profile, phytochemistry and pharmacology of Asparagus racemosus (Shatavari): A review. Asian Pacific Journ. of Trop. Dis., 3(3): 242-251.

Anandan R., Sudhakar D., Balasubramanian P. and Mera A.G., 2012. In vitro somatic embryogenesis form suspensor culture of Carica papaya L. Sci. Hortic., 136: 43-49.
Asha R. and Pawan K., 2012. Seed germination behavior of Asparagus racemosus under in vivo and in vitro conditions. Asian Journ Plant Sci. and Res., 2(4): 409-413.

Azad M.A.K. and Mohmad N.A., 2017. Regeneration of Asparagus officinalis through embryogenic callus. Plant Tissue Cult. and Biotechnol., 27(1): 21-31.

Bakheet S.A., 2010. In vitro preservation of Asparagus officinalis,. Biologia Planetarium, 43(2): 179183.

Bansode F.W., Arya K.R., Singh R.K. and Narendra T., 2014. Dose dependent effects of Asparagus adeceudents root extract on anabolic, reproductive and sexual behavioral activity in rats. Pharmaceutical Biology, 2014: 1-9.

Bojnauth G., Puchooa S. and Bahorun T., 2010. In vitro regeneration of Asparagus officinalis. Primary results, Food and Agriculture Research Council, Reduit, Mautitius, pp-7.15.

Bopana N. and Saxena S., 2008. In vitro propagation of high valued medicinal plant Asparagus racemosus willd. In vitro Cell Dev. Biol., 44: $525-532$.

Bopana N. and Saxena S., 2007. Asparagus racemosus, Ethnopharmacological evaluation and conservation seeds. Journ. of Ethnopharmc., 110: $1-15$.

Chaudhary J. and Dantu P.K., 2019. Induction of somatic embryos in cultures of Asparagus racemosus willd: an endangered medicinally important plant. Bull. National Res. Centre, 43: 113-117.

Chuadhary J. and Dantu P.K., 2011. Collection, establishment, acclimatization and quantification of Shatavar in IV in the medicinally important plant Asparagus racemosus willd. Chem. Of Phytopotential Health Energy and Env., pp.8386.

Chaudhary J., Shivraj S.M., Khatri P., Klepadla M., Dhakate R., Kumawat G., Patil G., Sonah H., Pataparkhe M., Deshmukh R. and Nygen H.I., 2018. Approaches, Applicability and challenges for development of climate smart Soybean. Oil Seed Crop., pp. 1-74.

Datta G.K., Sairam K., Priyambda S., Debnath P.K. and Goel R.K., 2002. Antiulcerogenic activity of 
Satavari manduran, Ayurvedic herbomineral preparation. Indian J. Exp. Biol., 40(10): 11731177.

Dezfuli S.A.F., Khanyani B.H. and Karimaneh Z., 2013. Optimization of callus induction and seedling regeneration in Asparagus (Asparagus officinalis). Bull. of Env. Pharmacol. and Life Sci., 2(2): 05-08.

Dinan I., Savchenko T. and Whiting P., 2001. Phytoecdysteroids in the genus Asparagus (Asparagaceae). Phytochemistry, 56: 569-576.

Elimra S., Anush V., Ali P. and Ani B., 2017. Elaboration of Asparagus officinalis L. by in vitro and Hydroponic. American J. Microbiol. \& Biotech., 2(6): 82-86.

Goel R.K., Prabha T., Kumar M.M., Dora B., Prakash M. and Singh G., 2006. Teratogenecity of Asparagus racemosus willd root a herbal medicine. Ind. Journ. of Exper. Biol., 44(7): 570-573.

Gyulai G., Janovsky J., Kisc E., Lelik L. and Csillag A., 1992. Callus initiation and plant regeneration from inflorescence primordial of intergeneric hybrid Agropyron repens (L) on modified nutritive medium. Plant Cell Reports, 11(5-6): 366-369.

Joshi T., Sah S.P. and Singh A., 2012. Antistress activity of ethanolic extract of $A$. racemosus willd roots in mice. Ind. J. of Exper. Biol., 50(6): 419-424.

Kohmura H., Chokyu S. and Harad T., 1994. An efficient micropropagation system using embryogenic calli induced form bud cluster of Asparagus officinalis L. J. Japan Soc. Hort. Sci., 63: 51-59.

Lin Z.K., Chen Z.D., Cai, K.X., Yang J.J. and Zhang T.X., 2008. A study on effect of several plant growth regulators on rooting of white Asparagus (Asparagus officinalis L.) test tube seedling from anther culture. Act Agriculture Univ., 30(4): 651-655.

Lomror R., Jat B.L. and Yadav B.L., 2018. In vitro conservation of medicinal plant (Asparagus racemosus). J. of Pharmacognosy and Phytochemistry, 7(1): 1818-1822.

Mahendra G. and Bai V.N., 2012. Direct somatic embryogenesis and plant regeneration from seed derived protocorm of Cymbidium bicolor. Sci. Hortic., 135: 40-44.

Mandal S.C., Nandy A., Pal M. and Saha P., 2000. Evaluation of antibacterial activity of Asparagus racemosus willd root. Phytother Research, 14: 118-119.

Martin K.P., 2004. Plant regeneration through somatic embryogenesis in medicinally important Centella asiatica L. In vitro Cell Dev. Biol., 40: 586-591.

Mathur A., Shukla Y.N., Pal M., Ahua P.S. and Uniyal G.C., 1994. Saponin production in callus and cell suspension cultures of Panax quinquefolium. Phytochem., 35(5): 1221-1225.

Mehta S.R. and Subramanian R.B., 2005. Direct in vitro propagation of Asparagus adsceudes. Plant Tissue Cult., 15(1): 25-32.

Mustapha B., Mukhopadhyay S. and Yves D., 1996. Optimization of callus culture and shoot multiplication of Asparagus densiforus. Plant Cell Tissue and Org. Cult., 47: 91-94.

Nishritha B. and Sanjay S., 2008. In vitro propagation of high valued medicinal plant, Asparagus racemosus willd. 44(6-12): 525-532.

Ojha R., Sahu A.N., Muruganandam A.V., Singh C.K. and Krishna Murthy S., 2010. Asparagus racemosus enhances memory and protects against amnesia in rodent model. Brain and Cognition, 74: 1-9.

Pank K.K. and Joshi S.D., 2017. In vitro morphogenesis of shoot induced callus of Asparagus racemosus willd. into somatic embryoids. Int. J. of Technic. Res. and Sci., 2(10): 637-641.

Patel L.S. and Patel R.S., 2015. Rapid in vitro micropropagation of Asparagus racemosus willd from nodal explants. Int. J. Curr. Microbiol. Appl. Sci., 4(5): 607-617.

Pise M., Rudra J., Bundale S., Begde D., Nandita N. and Upadhyay A., 2011. Satavarin production from in vitro cultures of Asparagus racemosus willd. Journal of Medicinal Plant Research, 5(4): 507513.

Ren J., Wenjing C. and Mikolaj K., 2012. Factors affecting (Asparagus officinalis L.) Root development in vitro. 
Saxena V.K. and Chaurasia S., 2001. A new isoflavone from the roots of Asparagus racemosus. Fitoterapia, 72: 307-309.

Shao Y.V., Poobsacert O., Kennelly E.J., Chin C.K., HO C.T., Huang M.T., Garrison A. and Cordell G.A., 1997. Steroid saponins from Asparagus officinalis and their cytotoxic activity. Planta Medica, 63: 258-262.

Sharma A. and Sharma V., 2013. A brief review of medicinal properties of Asparagus racemosus (Shatawari). Int. J. of Pure and Appl. Biosci., 1(2): 48-52.

Sharma O.P., Kumar N., Singh B. and Bhat T.K., 2012. An improved methods for thin layer chromatography analysis of Saponins. Food Chemistry, 132: 671-674.

Sharma P., Chauhan P.S., Dutt P., Amina M., Suri K.A., Gupta B.D., Suri O.P., Dhar K.L., Sharma D.,
Gupta V. and Satti N.K., 2011. A unique immune-stimulant steroidal sapogenin acid from the roots of Asparagus racemosus. Steroids, 76(4): 358-364.

Singh G.K., Garabandhu D., Muruganandam A.V., Joshi V.K. and Drishnamurthy S., 2009. Antidepressant activity of Asparagus racemosus in rodent models. Pharmacology, Biochemistry and Behavior, 91(3): 283-290.

Trivedi M., Yadav S.K., Yadav G.K., Bhaskar R. and Tiwari R.K., 2010. Thidiazuron induced callus induction and in vitro regeneration of Asparagus racemosus. Indian J. Sci. Res., 1(1): 27-30.

Zhang C.R., Huang X.L., Wu J.Y., Feng B.H. and Chen Y.F., 2006. Identification of Thidiazuron induced ESTs expressed differentially during callus differentiation of alfalfa Medicago sativa. Physiologia Plantarum, 128(4): 732-739. 